\title{
Forest fire risk mapping using analytical hierarchy process (AHP) and earth observation datasets: a case study in the mountainous terrain of Northeast India
}

\author{
Ridalin Lamat $^{1} \cdot$ Mukesh Kumar $^{1}$ [D $\cdot$ Arnab Kundu $^{2} \cdot$ Deepak Lal $^{1}$
}

Received: 9 December 2020 / Accepted: 16 February 2021 / Published online: 6 March 2021

(c) The Author(s) 2021 OPEN

\begin{abstract}
This study presents a geospatial approach in conjunction with a multi-criteria decision-making (MCDM) tool for mapping forest fire risk zones in the district of Ri-Bhoi, Meghalaya, India which is very rich in biodiversity. Analytical hierarchy process (AHP)-based pair-wise comparison matrix was constructed to compare the selected parameters against each other based on their impact/influence (equal, moderate, strong, very strong, and extremely strong) on a forest fire. The final output delineated fire risk zones in the study area in four categories that include very high-risk, high-risk, moderate-risk, and low-risk zones. The delineated fire risk zones were found to be in close agreement with actual fire points obtained from Moderate Resolution Imaging Spectroradiometer (MODIS) fire data for the study area. Results indicated that Ri-Bhoi's $804.31 \mathrm{sq} . \mathrm{km}$. (32.86\%) the area was under'very high' fire susceptibility. This was followed by $583.10 \mathrm{sq} . \mathrm{km}$. (23.82\%), 670.47 sq. km. (27.39\%), and $390.12 \mathrm{sq.} \mathrm{km.} \mathrm{(15.93 \% )} \mathrm{the} \mathrm{area} \mathrm{under} \mathrm{high,} \mathrm{moderate,} \mathrm{and} \mathrm{low} \mathrm{fire} \mathrm{risk} \mathrm{categories,} \mathrm{respec-}$ tively. These results can be used effectively to plan fire control measures in advance and the methodology suggested in this study can be adopted in other areas too for delineating potential fire risk zones.
\end{abstract}

Keywords Forest fire $\cdot$ MCDM $\cdot$ AHP $\cdot$ Geospatial approach $\cdot$ Northeast India

\section{Introduction}

Natural conservation areas that play an important role in maintaining the environmental balance are found in developing tropical regions forests [1-3]. Despite being of paramount importance, forest cover loss in these regions is occurring at an alarming rate [4-6]. Over the last few decades, decline in forest cover has been attributed to wildfires, rapid economic development, agriculture, logging, and increasing human population [7-10]. Globally, approximately, $30 \%$ of tropical forests were degraded by logging or fire between 2000 and 2012 [11, 12].

In India, approximately, $64 \%$ of the total forest area is frequently affected by forest fires [13], causing an economic loss of over 440 crores [14]. Forest fires can be caused naturally (e.g., lighting) and/or induced via human activities, however, in India the latter is dominant. About $90 \%$ of the forest fires in India are caused by humans [15]. Over the last few years, forest fires in India have received greater attention because of their ecological, economic, social, climatic, and political impacts [16]. Despite the fact that forest fires are mostly regulated by anthropogenic factors, local environment, metrological condition, and topography factors also play an important role in their uncontrolled expansion. In this regard, it is very important to identify vulnerable areas that come under "forest fire risk zones." Therefore, parameters that play an

$\triangle$ Mukesh Kumar, mukeshkumar.fo@gmail.com | ${ }^{1}$ Centre for Geospatial Technologies, Sam Higginbottom University of Agriculture, Technology and Sciences, Prayagraj, Uttar Pradesh, India. ${ }^{2}$ Department of Geo-Informatics, P.R.M.S. Mahavidyalaya, Bankura University, Bankura, West Bengal, India. 
important role in forest fire need to be quantified timely with advanced technology.

Timely and accurate information of complex fire models needs spatial and temporal information that is furnished by geospatial technologies [17-21]. Additionally, integration of multi-criteria decision-making (MCDM) in spatial domain provides a novel framework toward the assessment of fire risk zones $[2,16,22-28]$. The AHP method is among the most widely used MCDM [29]. AHP along with geospatial techniques has been successfully utilized for identifying the fire risk zones in many parts of the world [3, 30-35].

The present study focuses on Ri-Bhoi district of Meghalaya state which lies in the northeastern (NE) region of India. In this region, slash and burn shifting cultivation, locally known as 'Jhum, plays an important role in a forest fire [36-38]. Being a forest-dominated region, forest fire risk assessment in this area is the need of the hour [39]. Additionally, no such methodology/model prior to the present study has been explored for mapping fire risk zones in the study area. The present study expects to aid in devising and adopting appropriate strategies for avoiding/minimizing the damage caused by forest fires in the study area.

\section{Study area}

The Ri-Bhoi district of Meghalaya lies between $91^{\circ} 20^{\prime} \mathrm{E}$ and $92^{\circ} 20^{\prime} \mathrm{E}$ longitude and $25^{\circ} 20^{\prime} \mathrm{N}$ and $26^{\circ} 20^{\prime} \mathrm{N}$ latitude of the northeast region of India (Fig. 1). It covers an area of $2448 \mathrm{sq} . \mathrm{km}$. and is bounded by Kamrup district of Assam in the North, Karbi Anglong district of Assam and Jaintia Hills in the East, East Khasi Hills district in the South and West Khasi Hills district in the West of the state. The major forest species of the study area were Tectonagrandis (Teak), Shorea robusta (Sal), Bambusa vulgaris (bamboo), Thysanolaena (broom grass), Arundinaria or cane. According to census $2011,71 \%$ of the population in this region was engaged in agriculture where the traditional method of shifting cultivation was the dominant form of practice for agriculture. The important agricultural products of the region were Oryza sativa (Rice), Zea mays (Maize), Oilseeds, Ananas comosus (Pineapple), Musa paradisiacal (Banana), Carica papaya (Papaya), Artocar pus heterophyllus (Jackfruit), Manihot esculenta (Cassava), Zingiber officinale (Ginger) on which major portion of the population in the district depends for their livelihood. In summer, the climate of the district is hot and humid. Maximum temperature in the northern part of districts goes up to $31.06{ }^{\circ} \mathrm{C}$ during summer, whereas winter is mild with a temperature rising to $20.04^{\circ} \mathrm{C}$.
The area was inhabited by the Bhois, a Khasi sub-tribe. The district had an elevation of 25-1358 $\mathrm{m}$ above mean sea level where Sohpetbneng $(1350 \mathrm{~m})$ and the Raitong $(1237 \mathrm{~m})$ were the most important peaks of the district. The soil of the district was derived from Gneissic complex parent materials; they were dark reddish-brown where the texture of soil varied from loamy to fine loamy, whereas the areas bordering Assam were mostly covered with alluvial soil. The important rivers flowing through this region include the Umtrew, Umsiang, Umran, and Umiam. Ri-Bhoi district was a dwelling to numerous flora and fauna known as the Nongkhyllem Wildlife Sanctuary. The study area mostly belonged in a rural area where several agricultural products, fruits, oilseeds, etc., were sold in the various market of the district. Shifting cultivation was the dominant source of livelihood in this region as a substantial portion of the population depended on it for their economic profits. For the farmers, shifting cultivation became more of traditional beliefs than just agricultural practice. Shifting cultivation was more preferable to the modified cropping cultivation because of the economic conditions and requires less labor for farming. The population of this area is on a steady rise causing high demand for agricultural land ultimately increasing forest cover loss. Further, loss in the forest cover is also influencing biodiversity and soil erosion in the study area.

\section{Materials and methods}

\subsection{Generation of thematic layers using remote sensing and geographic information system (GIS)}

In this study, the parameters used for the forest fire risk zone mapping are population density, elevation, slope, aspect, temperature, rainfall, wind speed, and land use/ land cover (LULC) which has been derived from the earth observation satellite and ancillary data.

LULC map of the study area was prepared using Landsat 5 Thematic Mapper (TM) using supervised classification. Furthermore, Advanced Spaceborne Thermal Emission and Reflection Radiometer (ASTER)-derived Digital Elevation Model (DEM) was acquired from the United States Geological Survey (USGS) Earth Explorer (www.earthexplorer. ugs.gov) with a resolution of $30 \mathrm{~m}$ for elevation, slope, and aspect purpose as well as monitoring the vulnerability of forest fire risk zone. However, meteorological datasets viz. temperature, rainfall, and wind speed were downloaded from Global Weather data (www.globalweather.tamu.edu) for 16 different meteorological stations which were present in the district and its neighboring areas. The monthly average of meteorological data was interpolated by the 


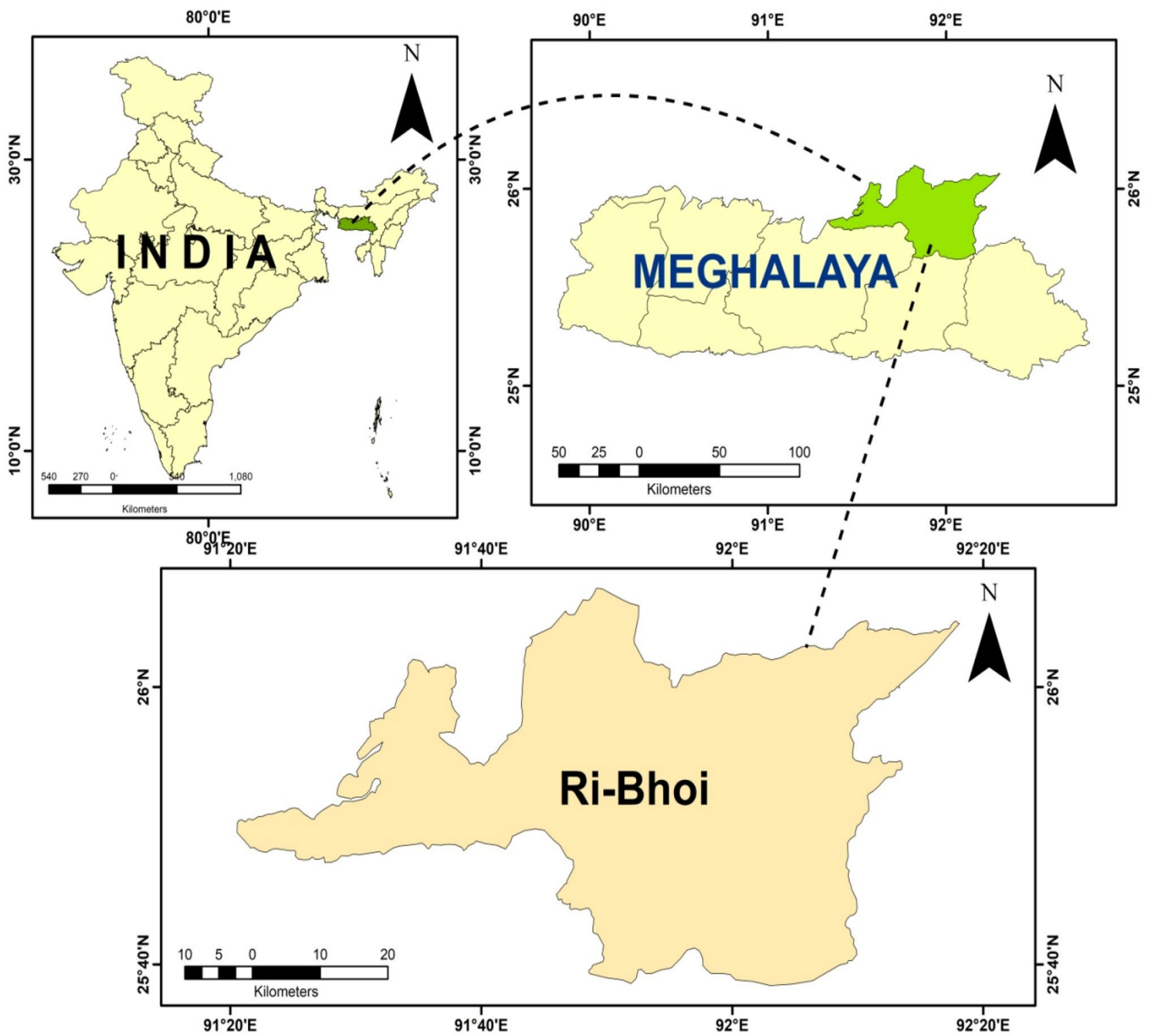

Fig. 1 Location of the study area

Inverse Distance weight method (IDW) method in the GIS environment. In addition, a population density map was generated from the census data [40] using a spatial interpolation tool through ArcGIS software. Subsequently, all the thematic layers were generated in raster format using the raster converter tool using ArcGIS. However, the overall methodology of the present study is shown in Fig. 2.

\subsection{Assignment of weight to different thematic layer using AHP}

Assessment of weight of each thematic layer is the most important for prediction of forest fire zone as output is mostly dependent on appropriate weight. Most important methodologies were adopted for calculating weightage to delineate the fire risk zone such as fuzzy sets [41], linguistic variables [42], and AHP [43]. However, AHP is the most frequently used method for determining fire risk zone [16, 44]. AHP was a decision added method that generated relative ratio scales of paired comparison developed by Saaty [43]. In the present study, AHP-based pair-wise comparison matrixes were made between different thematic layers at each level of the hierarchy.

A pair-wise comparison matrix was made to compare all factors against each other based on their importance (equal, moderate, strong, very strong, and extremely strong). A standard Saaty's 1-9 scale was used to determine the relative importance values for all themes and 


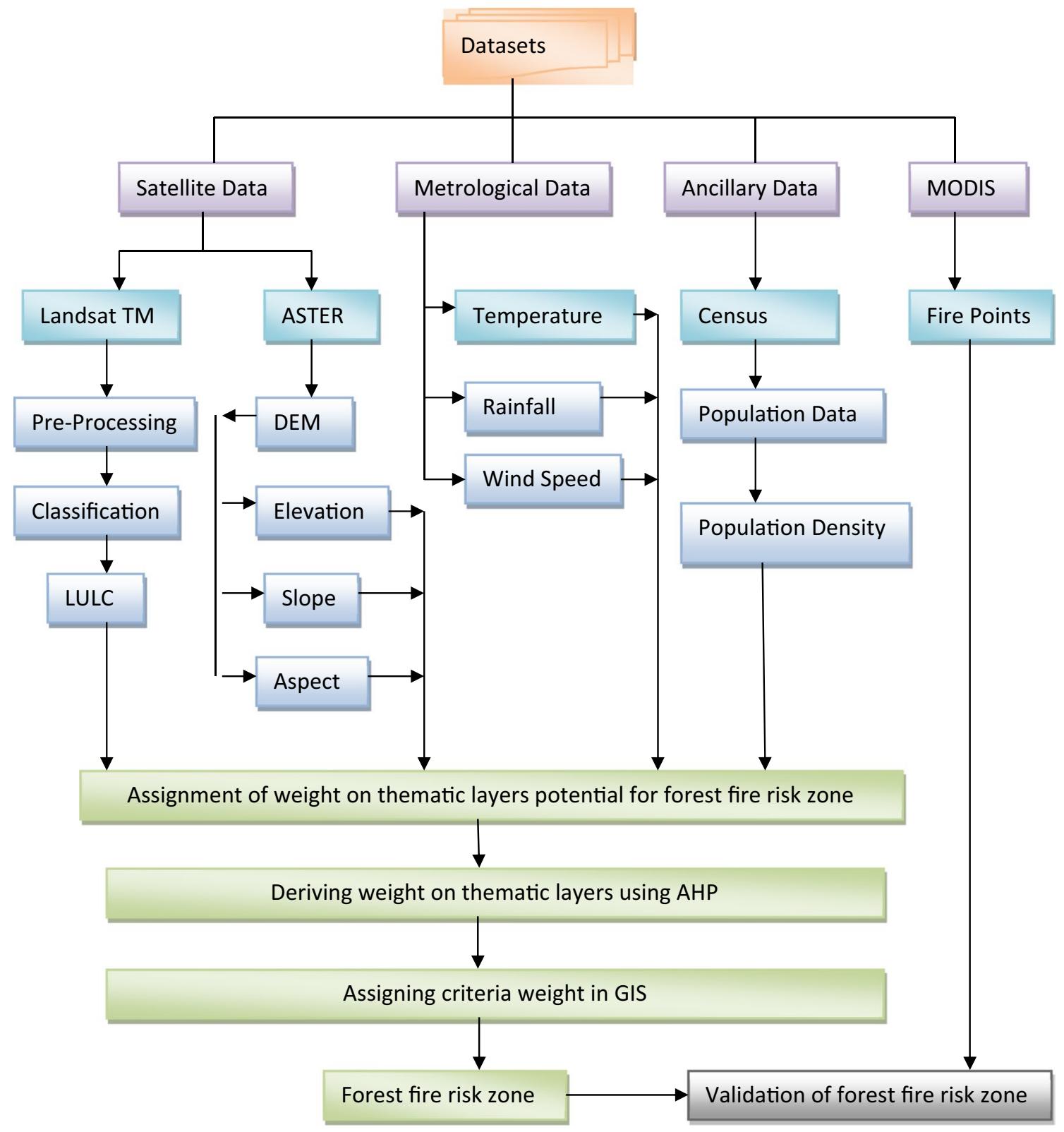

Fig. 2 Flowchart of methodology

their respective features, where value ' 1 ' denotes "equal importance" between the two themes, and the value ' 9 ' denotes the "extreme importance" of one theme compared to the other one shown in Table 1 [43]. The normalized relative weight was calculated by dividing each element of the pair-wise matrix by the sum of its column. The weights of each layer were decided using the principal eigenvector of the square matrix of each criterion. The higher was the weights the more was the influence of the parameters on the forest fire based on its relative importance.

The following equations were adopted to derive the weights of each of the thematic layers:
Table 1 Scale for a pair-wise comparison matrix

\begin{tabular}{ll}
\hline Intensity importance & Linguistic variables \\
\hline 1 & Equal importance \\
2 & Equal to moderate importance \\
3 & Moderate importance \\
4 & Moderate to the strong importance \\
5 & Strong importance \\
6 & Strong to the very strong importance \\
7 & Very strong importance \\
8 & Very to the extremely strong importance \\
9 & Extreme importance \\
\hline
\end{tabular}


1. Sum the values in each column of the pair-wise comparison matrix using the formula (Table 5 in Appendix) (Eq. 1)

$L_{i j}=\sum_{n=1}^{n} C_{i j}$

where $L_{i j}$ is the total column value of the pair-wise comparison matrix and $C_{i j}$ is the criteria used for the analysis.

2. Divide each element in the matrix by its total row to generate a normalized pair-wise comparison matrix (Table 6 in Appendix) (Eq. 2).

$X_{i j}=\frac{C_{i j}}{L_{j}}$

where $X_{i j}=$ normalized pair-wise comparison matrix.

3. Divide the sum of the normalized row of the matrix by the number of criteria/parameter $(N)$ to generate the standard weight by using the following formula (Eq. 3):

$W_{i j}=\frac{\sum_{j=1}^{n} X_{i j}}{N}$

where $W_{i j}=$ standard weight.

4. For calculating the consistency vector values, the following formula was used (Eq. 4):

$\lambda=\sum_{i=1}^{n} C V_{i j}$

where $\lambda=$ consistency vector.

5. Consistency Index (Cl) was used as a deviation or degree of consistency which was then calculated using the following formula (Eq. 5):

$\mathrm{Cl}=\frac{\lambda-n}{n-1}$

where $\mathrm{Cl}=$ Consistency Index,$n=$ Number of criteria.

6. Consistency ratio $(\mathrm{Cr})$ is calculated by using the formula (Eq. 6):

$\mathrm{Cr}=\frac{\mathrm{Cl}}{\mathrm{Rl}}$

where $\mathrm{RI}=$ random inconsistency.
If the value of the Consistency ratio $(\mathrm{Cr})$ is less than or equal to 0.10 , then the inconsistency is acceptable. Random inconsistency (RI) values for ' $n$ ' number of criteria, i.e., number of parameters [43] (Table 2).

\subsection{Assignment of weights for forest fire risk zone}

The method of the weighted linear combination was applied to identify the forest fire risk zones. The weights of the different thematic layers were multiplied by the weights of features of each thematic layer and summed the products of all the attributes and obtained the total scores by using the formula (Eq. 7):

$\mathrm{TS}=\sum W \times R$

where TS=Total Score, $W$ and $R$ were the weight of the thematic layers and the weight of the features in the thematic layers, respectively.

\subsection{Validation of fire risk zone map using MODIS data}

The accuracy of the fire risk zone map was verified using the fire point's data of MODIS satellite for 2011 which was acquired from National Remote Sensing Centre (NRSC), Indian Space Research Organisation (ISRO), Bhuvan. The fire points were overlaid to the forest fire risk zone map of the study area. The percentage of an area which was evaluated from the spatial analyst tool in GIS and imported to Microsoft Excel environment for calculating risk zone percentage by Eq. 8 .

Then, the percentage (\%) of the area under fire was calculated using the equation given as follows

Percentage of an area $(\%)=\frac{\text { estimated area }}{\text { total area }} * 100$

\section{Results and discussion}

The analysis of forest fire risk zone in Ri-Bhoi district of Meghalaya was carried out using the eight parameters which include population density (PD), LULC, elevation
Table 2 Random inconsistency values [43]

\begin{tabular}{lllllllll}
\hline$n$ & 2 & 3 & 4 & 5 & 6 & 7 & 8 & 9 \\
\hline $\mathrm{RI}$ & 0 & 0.52 & 0.9 & 1.12 & 1.24 & 1.32 & 1.41 & 1.45 \\
\hline
\end{tabular}

where $\mathrm{n}=$ number of criteria used and $\mathrm{R}$ = Random Inconsistency 
(EL), temperature (TEMP), slope (SL), aspect (AS), wind speed (WS, and rainfall (RF).

\subsection{Population density}

An increase in population density is one of the main reasons behind the number of fire incidents in a forested landscape. Forest fire in northeast India is mainly caused by shifting cultivation, i.e., slash and burn agriculture. Past research work also has discussed that rapid population growth promotes the short fallow cycle in shifting cultivation in northeast India [45-48]. Many other studies throughout the world have also used the importance of population density in forest fire monitoring and mapping $[2,16,49]$.

In study area, population map has been categorized in four different classes, i.e., very high populated area (7658-16,809 persons/sq. km.), high populated area (2183-7058 persons/sq. km.), moderately populated area (470-2183 persons/sq. km.), and low populated area (9-470 persons/sq. km.) (Fig. 3). The final weightage for all subclasses is calculated and shown in Table 3.

\subsubsection{LULC}

LULC dynamics are mostly accelerated by human activities which caused many changes those affect various forests and environment ecosystem [50,51]. Many previous kinds of research have focused on the importance of land cover classes in evaluating the risk of a given area to fire events as it is related to fuel types and characteristics [16, 52-54].

In this study, LULC has been categorized into four different classes, i.e., forest land, agriculture/scrubland, settlement, and water body. Most of the fire areas were caused due to the slash and burnt of forest areas for cultivation purposes and forests such as very dense forest, dense forest, and the open forest have fallen under very high-risk zone which was accounted for $1417.06 \mathrm{sq} . \mathrm{km}$. (57.89\%) followed by agriculture/scrubland for 868.87 sq. km. (35.49\%), settlement areas for $72.93 \mathrm{sq} . \mathrm{km}$. (2.98\%), and water bodies comprised of 89.14 sq. km. (3.64\%) over the region. The scrubland was mainly due to the abandoned shifting cultivation of land (Fig. 4).

\subsubsection{Elevation}

Usually, a decreasing trend in forest fires is apparent with rising elevation due to lower temperatures and higher humidity as opposed to the regions at a lower elevation [55]. The elevation in the study area varied from 25 to $1358 \mathrm{~m}$ which was then reclassified into four classes, viz. low (25-364 m), moderate (364-583 m), high (583-821 m), and very high (821-1358 m), respectively, a map of which is presented in Fig. 5. It was found that forest fire incidents were mostly very high in numbers in the lower and moderate elevation ranges, whereas there were fewer fire incidents at high elevations in the study area. This can be attributed to the high moisture content in vegetation and
Fig. 3 Population density map of the study area

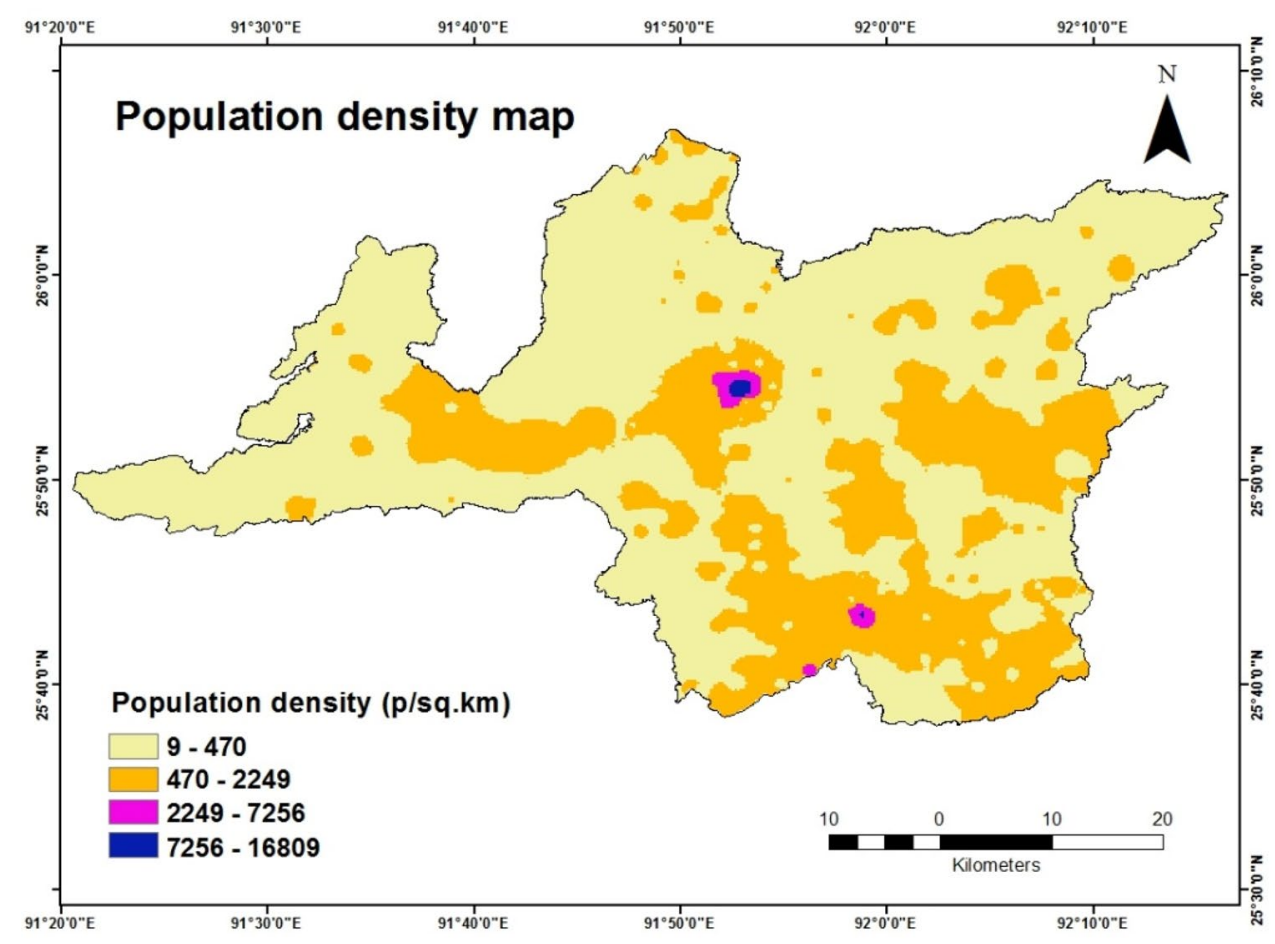


Table 3 Normalized and final weights of different features of thematic layer for assessment of forest fire zone

\begin{tabular}{|c|c|c|c|}
\hline Thematic layers & $\begin{array}{l}\text { Normalized } \\
\text { weight (\%) }\end{array}$ & Subclasses & Final weight \\
\hline \multirow{4}{*}{$\begin{array}{l}\text { Population density } \\
\left.\text { (person } / \mathrm{km}^{2}\right)\end{array}$} & \multirow[t]{4}{*}{0.33} & $7658-16,809$ & 0.19 \\
\hline & & $2183-7058$ & 0.09 \\
\hline & & $470-2183$ & 0.04 \\
\hline & & $9-470$ & 0.02 \\
\hline \multirow{4}{*}{$\begin{array}{l}\text { Land use/land } \\
\text { cover }\end{array}$} & \multirow[t]{4}{*}{0.23} & Forest & 0.13 \\
\hline & & $\begin{array}{l}\text { Agricultural/scrub- } \\
\text { land }\end{array}$ & 0.06 \\
\hline & & Settlement & 0.03 \\
\hline & & Water bodies & 0.01 \\
\hline \multirow[t]{4}{*}{ Elevation (m) } & \multirow[t]{4}{*}{0.15} & $25-364$ & 0.09 \\
\hline & & $364-583$ & 0.04 \\
\hline & & $583-821$ & 0.02 \\
\hline & & $821-1358$ & 0.008 \\
\hline \multirow[t]{4}{*}{ Temperature $\left({ }^{\circ} \mathrm{C}\right)$} & \multirow[t]{4}{*}{0.11} & $28-31$ & 0.06 \\
\hline & & $27-28$ & 0.03 \\
\hline & & $25-27$ & 0.01 \\
\hline & & $23-25$ & 0.006 \\
\hline \multirow[t]{4}{*}{ Slope (degree) } & \multirow[t]{4}{*}{0.07} & $45-61$ & 0.04 \\
\hline & & $30-45$ & 0.02 \\
\hline & & $15-30$ & 0.008 \\
\hline & & $0-15$ & 0.004 \\
\hline \multirow[t]{4}{*}{ Aspect } & \multirow[t]{4}{*}{0.06} & SW, S & 0.04 \\
\hline & & NW, W & 0.02 \\
\hline & & E, SE & 0.007 \\
\hline & & NE, N, Flat & 0.003 \\
\hline \multirow[t]{4}{*}{ Wind speed (m/s) } & \multirow[t]{4}{*}{0.04} & $1.32-1.42$ & 0.02 \\
\hline & & $1.25-1.32$ & 0.01 \\
\hline & & $1.19-1.25$ & 0.004 \\
\hline & & $1.11-1.19$ & 0.002 \\
\hline \multirow[t]{4}{*}{ Rainfall (mm) } & \multirow[t]{4}{*}{0.02} & $166-239$ & 0.01 \\
\hline & & $239-301$ & 0.005 \\
\hline & & $301-361$ & 0.002 \\
\hline & & $361-428$ & 0.001 \\
\hline
\end{tabular}

soil which made it unfavorable for ignition and spread of fire. The final weights of different elevation layers were calculated using AHP (Table 3).

\subsubsection{Temperature}

Temperature played an important role in a forest fire. High temperature helped to the rising rate of evapotranspiration where the seasonal drying of fuel, such as needles, leaves, twigs, and dead trees, resulted in inappropriate conditions that were suitable for an explosion of fire [56]. The average monthly temperature varied from 23 to $31^{\circ} \mathrm{C}$. The study area with high temperature was mostly in border areas of the state of Assam. However, the fire incidents were low because of low elevation ranges such as settlement areas, agricultural land, and less forest cover. The areas with low temperature were very few fire occurrences because of the moisture content present in fuel where the conditions were not very suitable for ignition of fire (Fig. 6).

\subsubsection{Slope}

The slope is an indicator of the rate of change of elevation. The rapid spread of fires usually moved faster uphill than downhill $[55,57]$. The steeper slope helped to spread fire because fuel was more dried on the upper slope than the lower slope. In the present study, the slope tended to very undulating even in low slope areas. Slope map of the study area was prepared from Cartosat-1 DEM data in ArcGIS and was divided into four classes as low (0-15\%), moderate (15-30\%), high (30-45\%), and very high (45-60\%) (Fig. 7). The region where the fire was mostly seen in a low and moderate slope $\left(0-30^{\circ}\right)$ since a major portion of forest cover was found in these slope areas.

\subsubsection{Aspect}

Aspect can be described as the direction of the maximum rate of change in elevation between each cell and its neighbors. An eastern part of the slope gets more sunlight early in the morning than a slope with a west aspect. Also, the southern part of the slope gets more sunlight in the northern hemisphere, so the temperature on the southern side was high and fuel gets dry easily. The southern aspect received more sunlight at a very high risk of forest fire [58]. The study area was classified into four classes, i.e., north and northeast; east and southeast; south and southwest; west and northwest (Fig. 8).

\subsubsection{Wind speed}

Wind speed is one of the weather conditions behaviors which have a massive influence on the intensity and fire spread of an area [59-62]. Also, the high temperature and hot strong winds together put the area at high risk of fire [63]. The monthly average of wind speed in the study area was $1.11-1.32 \mathrm{~m} / \mathrm{s}$. The speed of the wind was mostly high in low and moderate elevation, whereas it was low in high elevation ranges. In the present study, the upper part of the study area was having high wind speed than the lower part (Fig. 9).

\subsubsection{Rainfall}

Generally, rainfall affects both the moisture content of the fuel and the soil. The areas with high rainfall were fewer fire incidents due to the high moisture content of 
Fig. 4 Land use/land cover map of the study area

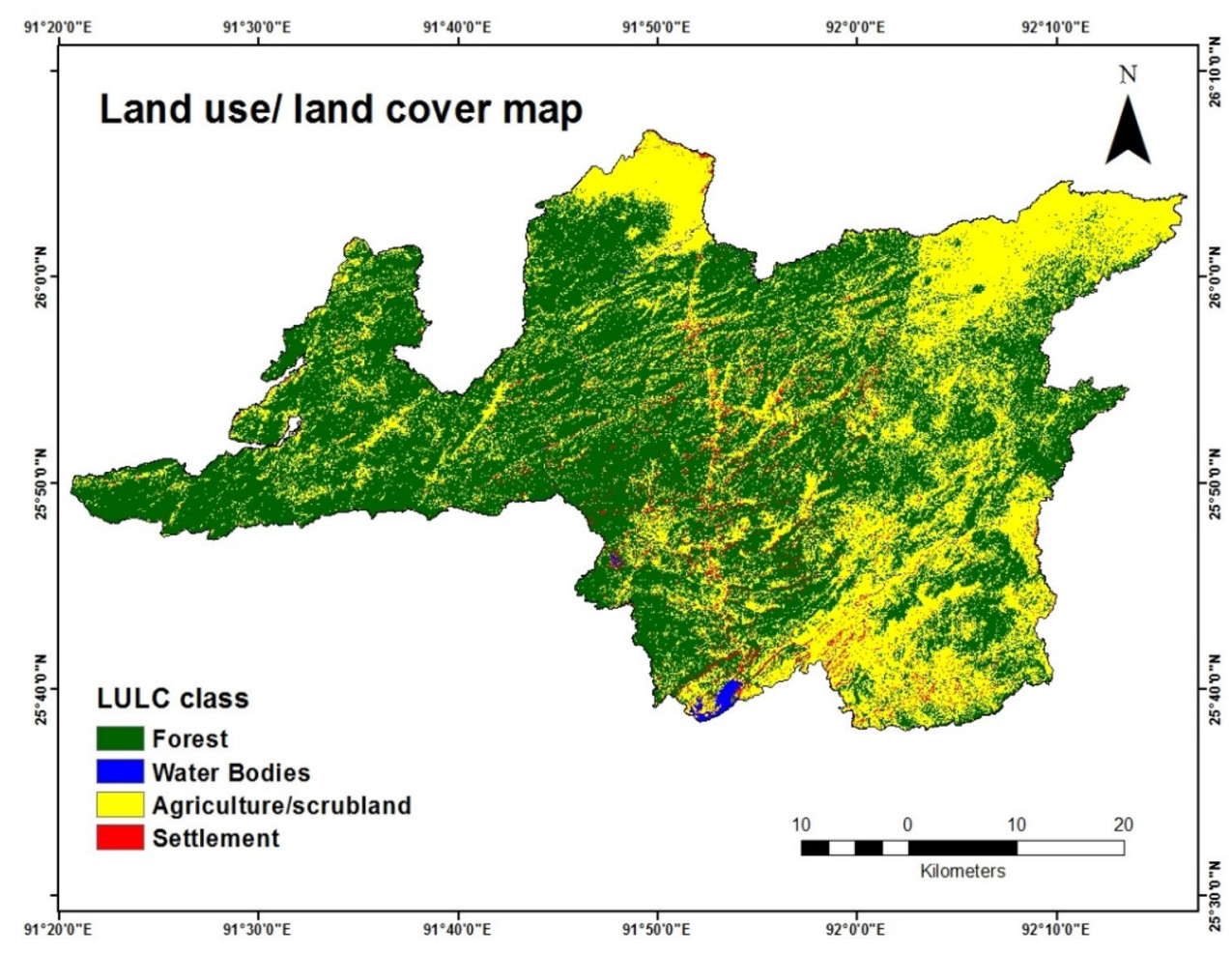

Fig. 5 Elevation map of the study area

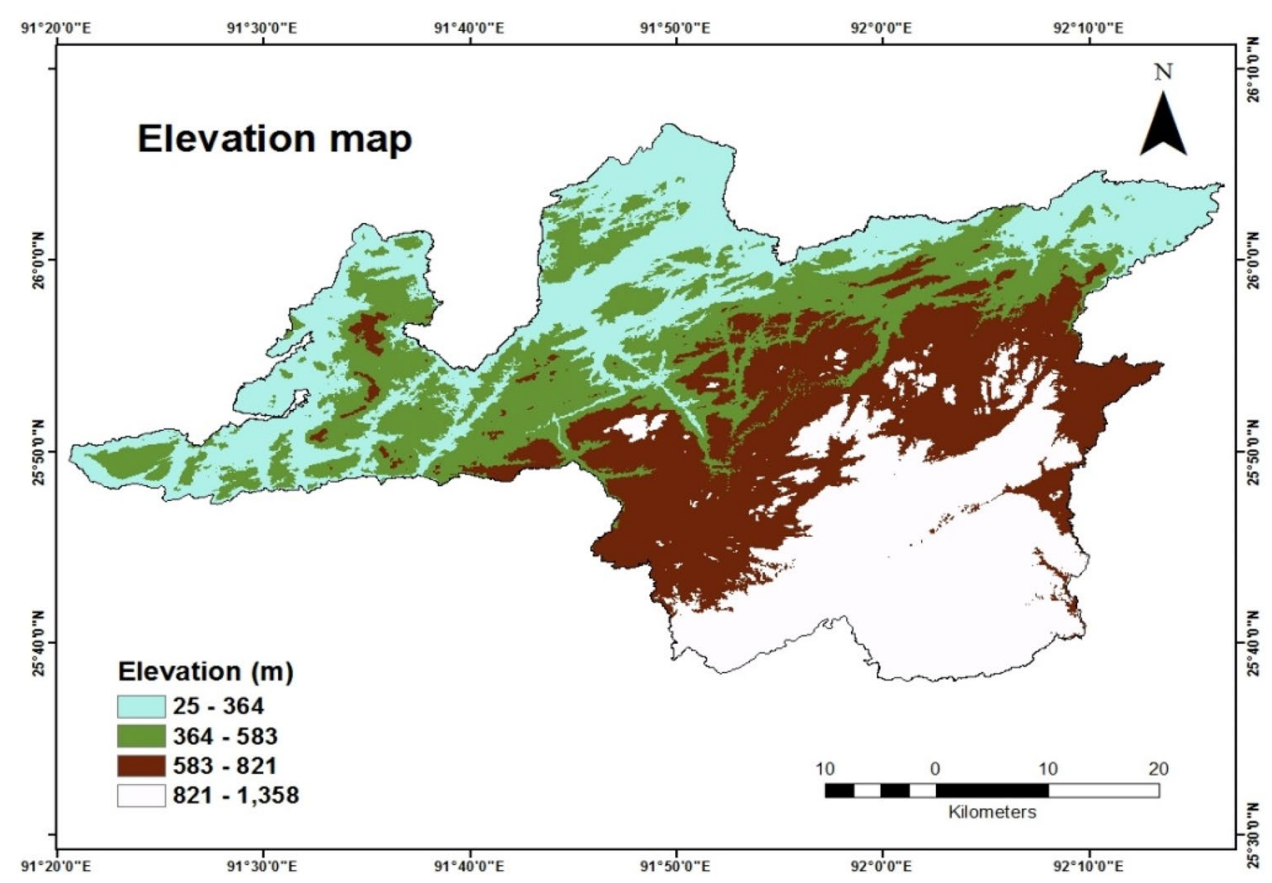

the fuel. The amount and time of rainfall played a crucial role in the physiological growth of vegetation and influenced the formation of forest fire [64]. The monthly average of rainfall in the study area was $166-428 \mathrm{~mm}$ showed higher elevation range caused ignition and spread of fire very low. There was a variation in rainfall concentration over the study area (Fig. 10). 
Fig. 6 Temperature map of the study area

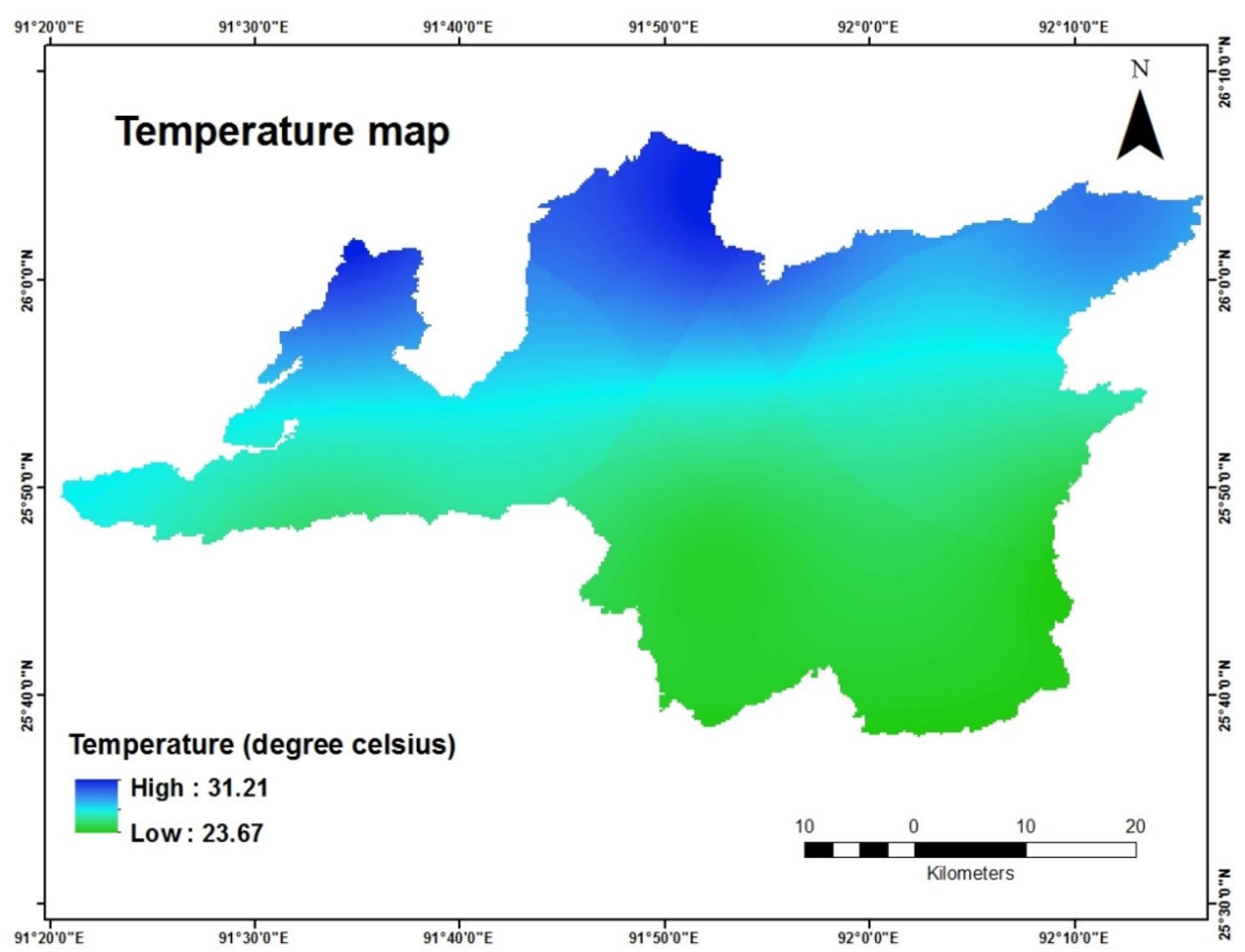

Fig. 7 Slope map of the study area

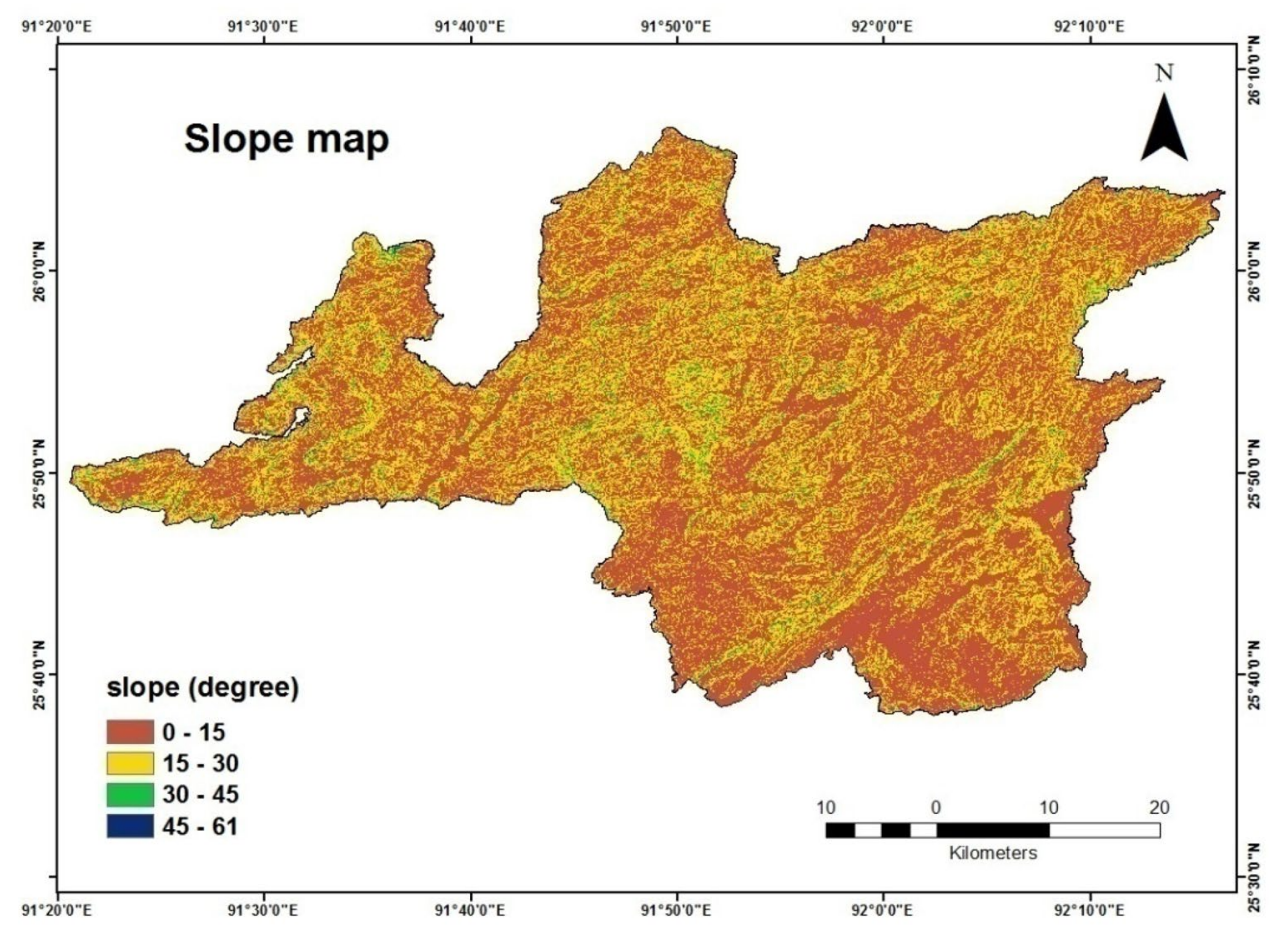

\subsection{Evaluation of forest fire risk zone}

The forest fire risk map was prepared by geospatial technology and the AHP method. After calculating the final weights of all parameters, it was converted to raster format and summed up using a raster calculator to demarcate the forest fire potential risk zone in ArcGIS software. The total score was obtained and classified into four distinct zones, namely low (9-14), moderate (14-18), high (18-23), and very high (23-30). The fire zones map was further processed by applying a majority filter in ArcGIS to avoid/minimize pixel speckling. Area of 804.31 sq. km. (32.86\%) came under a'very 
Fig. 8 Aspect map of the study area

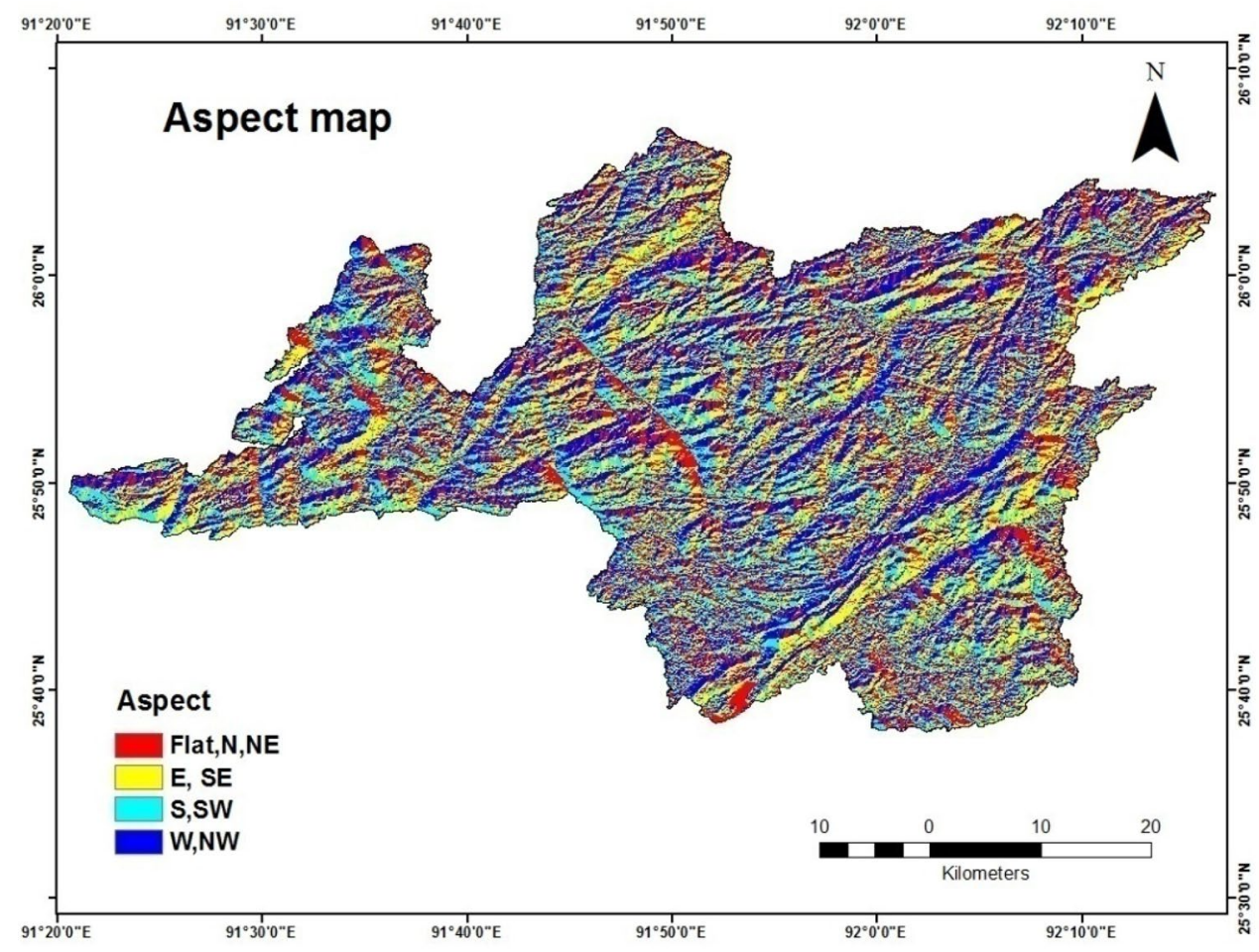

Fig. 9 Wind speed map of the study area

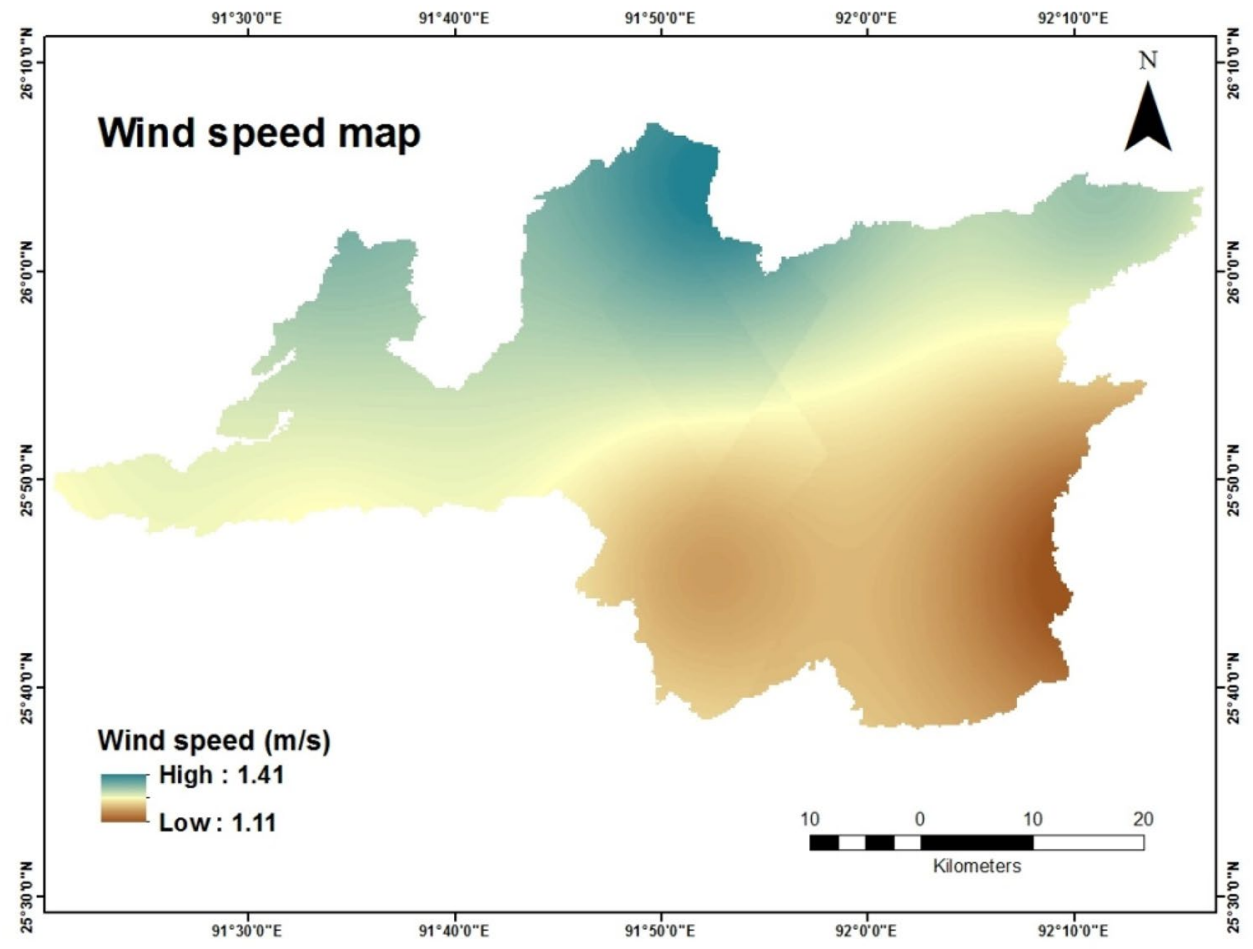

high' fire susceptibility risk zone followed by $583.10 \mathrm{sq} . \mathrm{km}$. (23.82\%) under high risk, $670.47 \mathrm{sq} . \mathrm{km}$. (27.39\%), moderate risk and 390.12 sq. km. (15.93\%) came under the low-risk category (Table 4). The potential areas for forest fires were mostly high in sparse population areas and concentrated mostly in the eastern part of the district where agriculture practice was very high. In addition, very high fire susceptibility areas were found mostly in the low elevation ranges of low slope especially in the southern area of the study area (Fig. 11). 
Fig. 10 Rainfall map of the study area

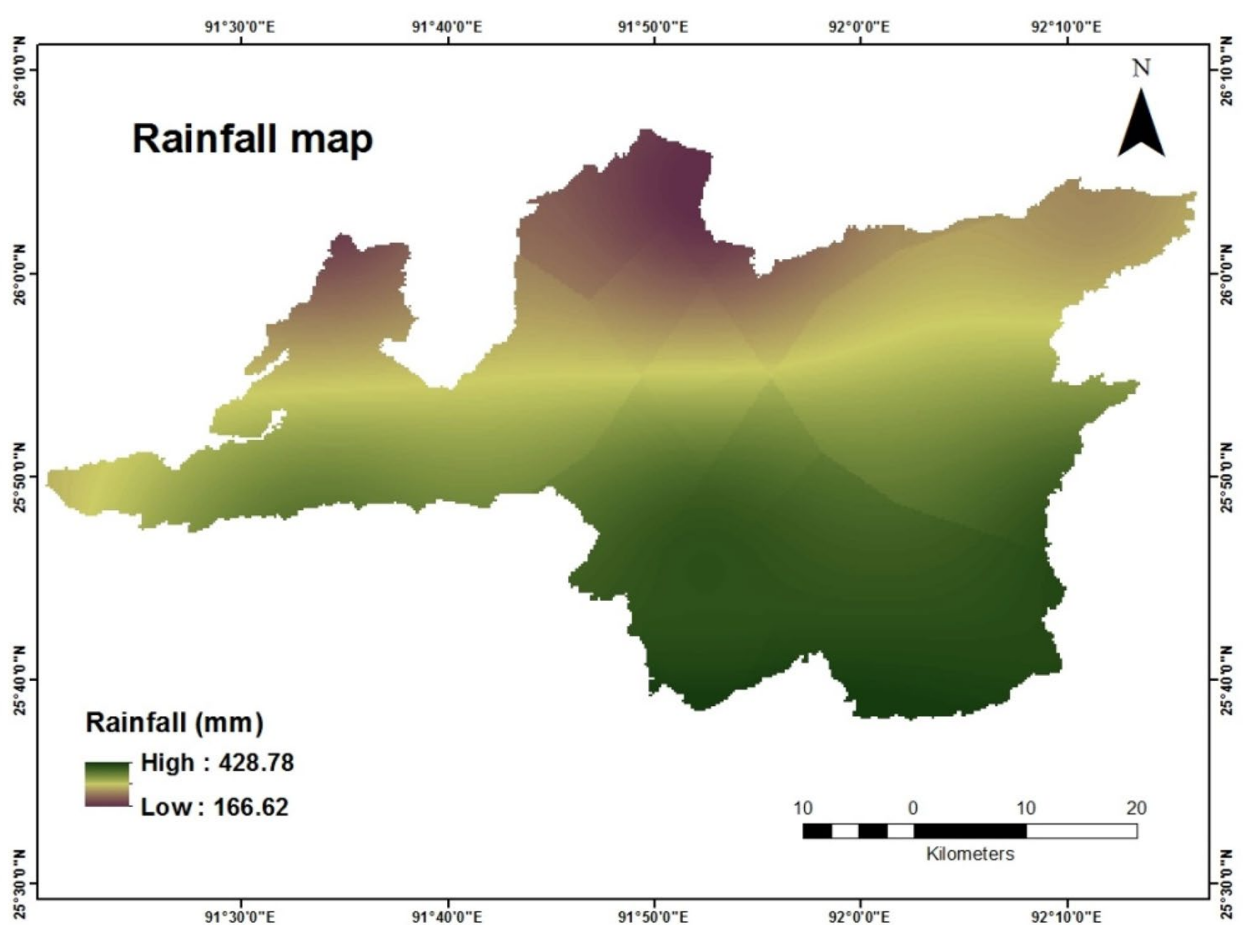

\section{Conclusion}

\begin{tabular}{lll}
\hline Fire risk zone & Area $($ sq. $\mathrm{km})$ & Percentage $(\%)$ \\
\hline Very high & 804.31 & 32.86 \\
High & 583.10 & 23.82 \\
Moderate & 670.47 & 27.39 \\
Low & 390.12 & 15.93 \\
\hline
\end{tabular}

\subsection{Validation of the forest fire risk zone}

The validation of the forest fire risk zone was verified by the fire points of MODIS satellite of the year 2011 which was acquired from NRSC (ISRO) (www.bhuvan.nrsc.gov.in). The fire was very prone in low to moderate elevation ranges and most of the fire points overlaid in the map were seen as very high-risk zone (Fig. 12).
Forest fires due to anthropogenic activity have been a major problem across tropical regions.

This study explores the application of geospatial technologies and the AHP method to assess fire risk in the Ri-Bhoi district of Meghalaya, India. In this study, parameters used for assessing fire risk are population, LULC, slope, aspect, elevation, temperature, rainfall, and wind speed. The final map of fire risk was categorized into four zones as very high, high, moderate, and low risk. Very high fire risk occupies $32.86 \%$ followed by high risk $27.39 \%$ and moderate risk $15.93 \%$ of the study area. Results obtained from this study could be useful for a local administrator to address broad-scale fire hazard concerns for future action. Additionally, the methodology adopted in this study can be applied to the tropical regions as well as another part of the NE region of India where a forest fire is a big problem. 
Fig. 11 Forest fire risk zone map

Fig. 12 Validation map of the forest fire risk zone
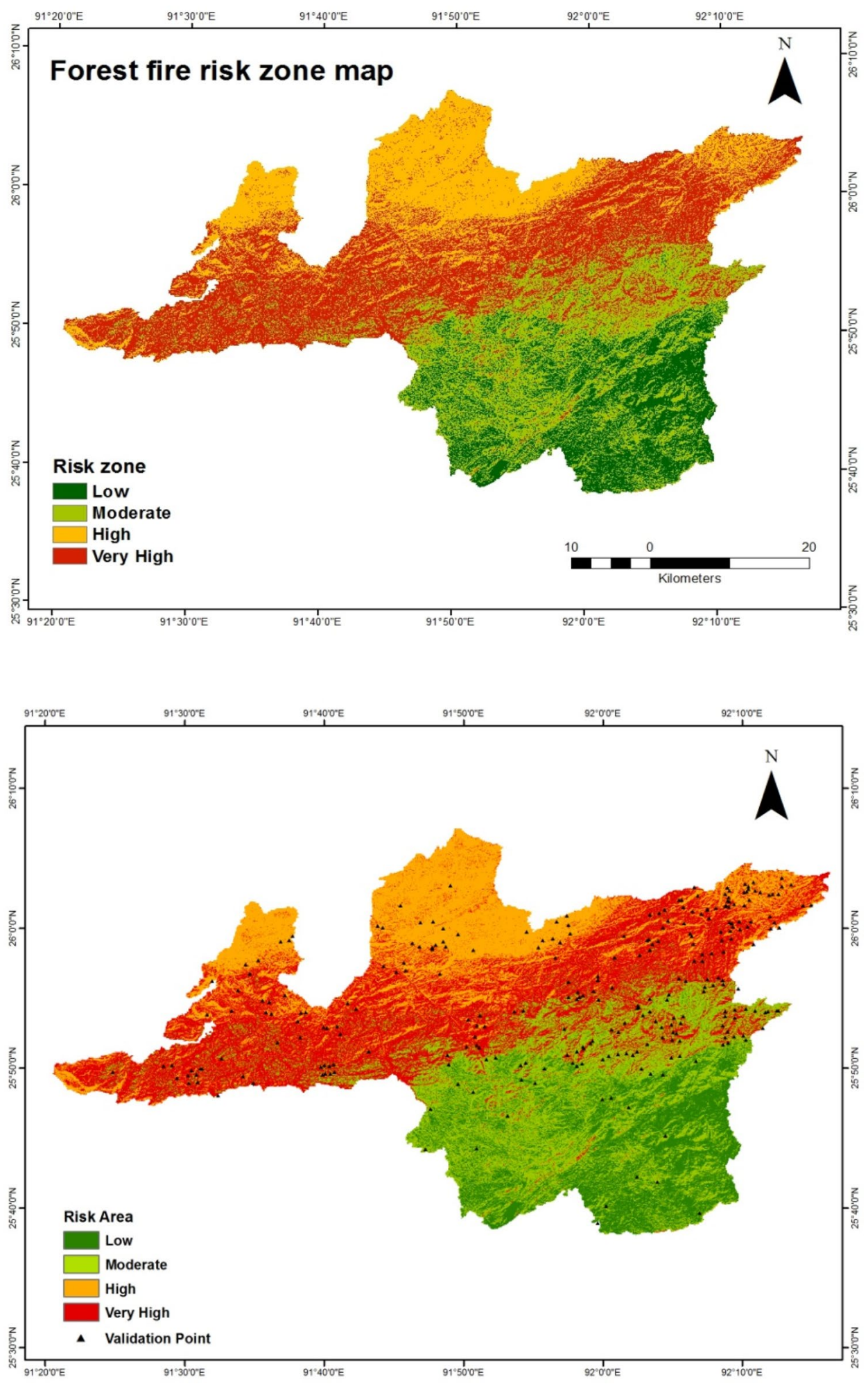


\section{Compliance with ethical standards}

Conflict of interest The authors declare that they have no conflict of interest.

Open Access This article is licensed under a Creative Commons Attribution 4.0 International License, which permits use, sharing, adaptation, distribution and reproduction in any medium or format, as long as you give appropriate credit to the original author(s) and the source, provide a link to the Creative Commons licence, and indicate if changes were made. The images or other third party material in this article are included in the article's Creative Commons licence, unless indicated otherwise in a credit line to the material. If material is not included in the article's Creative Commons licence and your intended use is not permitted by statutory regulation or exceeds the permitted use, you will need to obtain permission directly from the copyright holder. To view a copy of this licence, visit http://creativecommons .org/licenses/by/4.0/.

\section{Appendix}

Table 5 Pair-wise comparison matrix of the thematic layers

\begin{tabular}{lllllllll}
\hline & PD & LULC & EL & TEMP & SL & AS & WS & RF \\
\hline PD & 1 & 3 & 3 & 5 & 5 & 6 & 7 & 7 \\
LULC & 0.33 & 1 & 3 & 4 & 5 & 5 & 6 & 7 \\
EL & 0.33 & 0.33 & 1 & 3 & 3 & 4 & 5 & 5 \\
TEMP & 0.2 & 0.25 & 0.33 & 1 & 3 & 3 & 5 & 6 \\
SL & 0.2 & 0.2 & 0.33 & 0.33 & 1 & 2 & 3 & 7 \\
AS & 0.17 & 0.2 & 0.25 & 0.33 & 0.5 & 1 & 3 & 5 \\
WS & 0.14 & 0.17 & 0.2 & 0.2 & 0.33 & 0.33 & 1 & 5 \\
RF & 0.14 & 0.14 & 0.2 & 0.17 & 0.14 & 0.2 & 0.2 & 1 \\
Total & 2.51 & 5.29 & 8.31 & 14.03 & 17.97 & 21.53 & 30.2 & 43 \\
\hline
\end{tabular}

Table 6 Normalized pair-wise matrix

\begin{tabular}{lllllllllll}
\hline & PD & LULC & EL & TEMP & SL & AS & WS & RF & Total weight & Nor. Weight \\
\hline PD & 0.40 & 0.57 & 0.36 & 0.36 & 0.28 & 0.28 & 0.23 & 0.16 & 2.64 & 0.33 \\
LULC & 0.13 & 0.19 & 0.36 & 0.29 & 0.28 & 0.23 & 0.20 & 0.16 & 1.84 & 0.23 \\
EL & 0.13 & 0.06 & 0.12 & 0.21 & 0.17 & 0.19 & 0.17 & 0.12 & 1.17 & 0.15 \\
TEMP & 0.08 & 0.05 & 0.04 & 0.07 & 0.17 & 0.14 & 0.17 & 0.14 & 0.86 & 0.11 \\
SL & 0.08 & 0.04 & 0.04 & 0.02 & 0.06 & 0.09 & 0.10 & 0.16 & 0.59 & 0.07 \\
AS & 0.07 & 0.04 & 0.03 & 0.02 & 0.03 & 0.05 & 0.10 & 0.12 & 0.46 & 0.06 \\
WS & 0.06 & 0.03 & 0.02 & 0.01 & 0.02 & 0.02 & 0.03 & 0.12 & 0.33 & 0.04 \\
RF & 0.06 & 0.03 & 0.02 & 0.01 & 0.01 & 0.01 & 0.01 & 0.02 & 0.17 & 0.02 \\
\hline
\end{tabular}




\section{References}

1. Bonan GB (2008) Forests and climate change: forcings, feedbacks, and the climate benefits of forests. Science 320(5882):1444-1449

2. Suryabhagavan KV, Alemu M, Balakrishnan M (2016) GISbased multi-criteria decision analysis for forest fire susceptibility mapping: a case study in Harenna forest, southwestern Ethiopia. Trop Ecol 57(1):33-43

3. Nuthammachot N, Stratoulias D (2019) A GIS- and AHP-based approach to map fire risk: a case study of Kuan Kreng peat swamp forest, Thailand. Geocarto Int 36(2):212-225

4. Sanchez-Azofeifa GA, Harriss RC, Skole DL (2001) Deforestation in Costa Rica: a quantitative analysis using remote sensing imagery ${ }^{1}$. Biotropica 33(3):378-384

5. United Nations Environmental Programme (UNEP) (2002) Global environment outlook 3:92-807-2087-2, pp 1-424

6. Abdullah SA, Nakagoshi N (2007) Forest fragmentation and its correlation to human land use change in the state of Selangor, peninsular Malaysia. For Ecol Manag 241(1-3):39-48

7. Uusivuori J, Lehto E, Palo M (2002) Population, income and ecological conditions as determinants of forest area variation in the tropics. Global Environ Chang 12(4):313-323

8. Ajin RS, Ciobotaru AM, Vinod PG, Jacob MK (2015) Forest and wildland fire risk assessment using geospatial techniques: a case study of Nemmara forest division, Kerala, India. J Wetlands Biodivers 5:29-37

9. Bhuridej R, Stevens L (2016) Maximizing carbon sink capacity and conserving biodiversity through sustainable conservation, restoration and management of peat-swamp ecosystems. UNDP project. https://info.undp.org/docs/pdc/Documents/ THA/Peat\%20Swamps\%20Pro\%20Doc\%20Pages\%20with\%20 UNDP-ONEP\%20Signatures.pdf

10. Khampeera A, Yongchalermchai C, Techato K (2018) Drought monitoring using drought indices and GIS techniques in Kuan Kreng Peat Swamp, Southern Thailand. Walailak J Sci Tech 15(5):357-370

11. Asner GP, Rudel TK, Aide TM, Defries R, Emerson R (2009) A contemporary assessment of change in humid tropical forests. Conserv Biol 23(6):1386-1395

12. Coomes DA, Dalponte M, Jucker T, Asner GP, Banin LF, Burslem DFRP, Lewis SL, Nilus R, Phillips OL, Phua MH, Qie L (2017) Areabased vs tree-centric approaches to mapping forest carbon in Southeast Asian forests from airborne laser scanning data. Remote Sens Environ 194:77-88

13. Forest Survey of India (2003) State of forest report 2003. Ministry of Environment, Forest and Climate Change. http://www.fsi.nic. in/sfr2003

14. Gubbi S (2003) Fire, fire burning bright! Deccan Herald. Bangalore. India. http://www.wildfirefirst.info/images/wordfiles/fire. doc. Accessed Dec 2018

15. Roy PS, Diwakar PG, Vohra TPS, Bhan SK (1990) Forest resource management using Indian Remote Sensing Satellite data. Asian Pac Remote Sens J 3(1):11-16

16. Vadrevu KP, Eaturu A, Badarinath KVS (2010) Fire risk evaluation using multi-criteria analysis-a case study. Environ Monit Assess 166:223-239

17. Bonazountas M, Kallidromitou D, Kassomenos PA, Passas N (2005) Forest fire risk analysis. Hum Ecol Risk Assess 11(3):617-626

18. Vadrevu KP, Badarinath KVS (2009) Spatial pattern analysis of fire events in Central India-a case study. Geocarto Int 24(2):115-131

19. Ganteaume A, Camia A, Jappiot M, San-Miguel-Ayanz J, LongFournel M, Lampin C (2013) A review of the main driving factors of forest fire ignition over Europe. Environ Manag $51: 651-662$

20. Modugno S, Balzter $H$, Cole B, Borrelli P (2016) Mapping regional patterns of large forest fires in Wildland-Urban interface areas in Europe. J Environ Manag 172:112-126

21. Vallejo-Villalta I, Rodríguez-Navas E, Márquez-Pérez J (2019) Mapping forest fire risk at a local scale-a case study in Andalusia (Spain). Environments 6(3):1-22

22. Çalışkan E (2013) Planning of forest road network and analysis in mountainous area. Life Sci J 10(2):2456-2465

23. Yakubu I, Mireku-Gyimah D, Duker AA (2015) Review of methods for modelling forest fire risk and hazard. Afr J Environ Sci Tech 9(3):155-165

24. Thompson MP, Haas JR, Gilbertson-Day JW, Scott JH, Langowski P, Bowne E, Calkin DE (2015) Development and application of a geospatial wild Bre exposure and risk calculation tool. Environ Model Softw 63:61-72

25. Çalişkan E (2017) Planning of environmentally sound forest road route using GIS \& S-MCDM. Prelim Commun Šumarski List 11-12:583-591

26. Rasooli SB, Bonyad AE, Pir Bavaghar M (2018) Forest fire vulnerability map using remote sensing data, GIS and AHP analysis (case study: Zarivar Lake surrounding area). Casp J Environ Sci 16(4):369-377

27. Çalişkan E, Bediroglu S, Yildirim V (2019) Determination forest road routes via GIS-based spatial multi-criterion decision methods. Appl Ecol Environ Res 17(1):759-779

28. Novo A, Fariñas-Álvarez N, Martínez-Sánchez J, González-Jorge H, Fernández-Alonso JM, Lorenzo H (2020) Mapping forest fire risk-a case study in Galicia (Spain). Remote Sens 12(22):1-20

29. Rahmati O, Nazari Samani A, Mahdavi M, Pourghasemi HR, Zeinivand H (2015) Groundwater potential mapping at Kurdistan region of Iran using analytic hierarchy process and GIS. Arab J Geosci 8:7059-7071

30. Chavan ME, Das KK, Suryawanshi RS (2012) Forest fire risk zonation using remote sensing and GIS in Huynial watershed, Tehri Garhwal district, UA. Int J Basic Appl Res 2:6-12

31. Chowdhury EH, Hassan QK (2013) Use of remote sensingderived variables in developing a forest fire danger forecasting system. Nat Hazards 67:321-334

32. Chowdhury EH, Hassan QK (2015) Operational perspective of remote sensing-based forest fire danger forecasting systems. ISPRS J Photogramm Remote Sens 104:224-236

33. Pourghasemi H, Beheshtirad M, Pradhan B (2016) A comparative assessment of prediction capabilities of modified analytical hierarchy process (MAHP) and Mamdani fuzzy logic models using Netcad-GIS for forest fire susceptibility mapping. Geomat Nat Hazards Risk 7(2):861-885

34. Matin MA, Chitale VS, Murthy MSR, Uddin K, Bajracharya B, Pradhan $S$ (2017) Understanding forest fire patterns and risk in Nepal using remote sensing, geographic information system and historical fire data. Int J Wildland Fire 26:276-286

35. Van Hoang T, Chou TY, Fang YM, Nguyen NT, Nguyen QH, Xuan Canh P, Ngo Bao Toan D, Nguyen XL, Meadows ME (2020) Mapping forest fire risk and development of early warning system for NW Vietnam using AHP and MCA/GIS methods. Appl Sci 10(12):1-19

36. Ramakrishnan PS (1988) Sustainable development, climate change and tropical rain forest landscape. Clim Chang 39:583-600

37. Majumder M, Shukla AK, Arunachalam A (2011) Agricultural practices in Northeast India and options for sustainable management. Biodiversity, biofuels, agroforestry and conservation agriculture. Sustain Agric Rev 5:287-315 
38. Madhuri (2019) Burnt area assessment. M.Sc. Thesis, North Eastern Space Applications Centre and Central University of Karnataka, India, pp 1-30

39. Olaniya M, Bora PK, Das S, Chanu PH (2020) Soil erodibility indices under different land uses in Ri-Bhoi district of Meghalaya (India). Sci Rep 10:1-13

40. Census of India (2011) Office of the Registrar General \& Census Commissioner, India, Ministry of Home Affairs, Government of India. https://censusindia.gov.in/2011-common/censusdata 2011.html

41. Bellman RE, Zadeh LA (1970) Decision-making in a fuzzy environment. Manag Sci 17(4):141-164

42. Chen SJ, Hwang CL (1992) Fuzzy multiple attribute decisionmaking: methods and applications. Springer, Berlin, pp 1-536

43. Saaty TL (1980) The analytic hierarchy process: planning, priority setting and resource allocation. McGraw-Hill, New York, pp $1-287$

44. Sharma NR, Fernandes PJF, Pokarel JR (2014) Methodological development for forest fire hazard in Nepal. Revista Brasileira de Cartografia 66(7):1551-1566

45. Das BN (1979) Forestry in agriculture in the hills. In: Pakem B, Miri M, Bhattacharjee JB, Gupta P, Datta Ray B (eds) Northeast India council for Social Science Research, Shillong

46. Bhowmik S (1986) Land and economic development in the hill areas of North-Eastern region in land use pattern of North-East India. In: Dutta BB (ed). Gagan Publishers, Ludhiana, pp 11-18

47. Ramakrishnan PS (1993) Shifting agriculture and sustainable development: an interdisciplinary study from North-Eastern India, 1st edn. CRC Press, Boca Raton, pp 1-424

48. Bhatt BP, Pattanayak A, Tondon P (2007) Shifting cultivation: issues and strategies in the $\mathrm{NEH}$ region in biodiversity and its significance. In: Tondon P, Abrol YP, Kumaria S (eds) I. K. International, New Delhi, pp 262-273

49. Bistinas I, Oom D, Sá ACL, Harrison SP, Prentice IC, Pereira JMC (2013) Relationships between human population density and burned area at continental and global scales. PLoS ONE $8(12): 1-12$

50. Agarwal C, Green GM, Grove JM, Evans TP, Schweik CM (2002) A review and assessment of land-use change models: dynamics of space, time, and human choice, Technical Report, U.S. Department of Agriculture, Forest Service, Northeastern Research Station, Pennsylvania, USA, pp 1-67

51. Kumar M, Denis DM, Singh SK, Szabó S, Suryavanshi S (2018) Landscape metrics for assessment of land cover change and fragmentation of a heterogeneous watershed. Remote Sens Appl Soc Environ 10:224-233
52. Keane RE, Burgan R, van Wagtendonk J (2001) Mapping wildland fuels for fire management across multiple scales: integrating remote sensing, GIS, and biophysical modeling. Int J Wildland Fire 10(4):301-319

53. Koetz B, Morsdorf F, van der Linden S, Curt T, Allgöwer B (2008) Multi-source land cover classification for forest fire management based on imaging spectrometry and LiDAR data. Forest Ecol Manag 256(3):263-271

54. Szpakowski DM, Jensen JLR (2019) A review of the applications of remote sensing in fire ecology. Remote Sens 11(22):1-31

55. Rothermel RC (1983) How to predict the spread and intensity of forest and Range fires. Gen Tech Rep INT-143. USDA Forest Service. Intermountain Forest and Range Experiment Station, pp 1-168

56. Bonora L, Conese C, Marchi E, Tesi E, Montorselli NB (2013) Wildfire occurrence: integrated model for risk analysis and operative suppression aspects management. Am J Plant Sci 4(3A):705-710

57. Kushla JD, Ripple WJ (1997) The role of terrain in a fire mosaic of a temperate coniferous forest. Forest Ecol Manag 95(2):97-107

58. Mukherjee S, Raj K (2014) Analysis of forest fire of Meghalaya using geospatial tools. In: 15th ESRI India user conference 2014. https://www.esri.in/ /media/esri-india/files/pdfs/events/uc201 4/proceedings/papers/UCP0053.pdf

59. Bessie WC, Johnson EA (1995) The relative importance of fuels and weather on fire behavior in subalpine forests. Ecology 76(3):747-762

60. Keeley JE (2004) Impact of antecedent climate on fire regimes in coastal California. Int J Wildland Fire 13(2):173-182

61. Schoennagel T, Veblen TT, Romme WH (2004) The interaction of fire, fuels, and climate across rocky mountain forests. Bioscience 54(7):661-676

62. Adab H, Kanniah KD, Solaimani K (2013) Modeling forest fire risk in the northeast of Iran using remote sensing and GIS techniques. Nat Hazards 65:1723-1743

63. Rathaur S (2005) Fire risk assessment for tiger preybase in Chilla Range and vicinity, Rajaji National Park using remote sensing and GIS. M.Sc. thesis, Indian Institute of Remote Sensing, ISRO, Dept. of Space, Govt. of India, 4 Kalidas Road, Dehradun-248001, Uttarakhand, India

64. Pereira MG, Trigo RM, da Camara CC, Pereira JMC, Leite SM (2005) Synoptic patterns associated with large summer forest fires in Portugal. Agric For Meteorol 129(1-2):11-25

Publisher's Note Springer Nature remains neutral with regard to jurisdictional claims in published maps and institutional affiliations. 